\title{
From Adjectives to Quantifiers. Evidence from Old and Modern Catalan ${ }^{1}$
}

\author{
Bruno Camus Bergareche
}

Universidad de Castilla-La Mancha. Facultad de Letras

bruno.camus@uclm.es

Manuel Pérez Saldanya

Universitat de València. Facultat de Filologia

manuel.perez-saldanya@uv.es

Received: December 202010

Accepted: April 132011

\begin{abstract}
The history of indefinite quantifiers in Romance languages is basically the history of the development of new distributional patterns in the case of some Latin adjectives (Company 1991, 1997; Batllori 1998). This new distribution will contribute to the construction of the new subclass of Romance determiners we call Quantifiers. As explained by Zamparelli (2000), the growing structural complexity of the left margin of DetP entails the specialization of old word classes for those new positions. A Quantifier position creates thus the Quantifier word class. This is a longterm process, the effects of which are clearly seen in medieval Romance for words derived from adjectives, such as MULTUS and PAUCUS, but also in later Romance adjectives such as Catalan bastant or even in Contemporary Catalan with the word suficient, which has a similar meaning (Brucart; Rigau 2002, Camus 2005, 2008, 2009).
\end{abstract}

Keywords: Word Class; Distributional Patterns; Left Margin of DetP; Catalan Diachronic Syntax; Indefinite Quantifiers.

\section{Table of Contents}
0. Introduction
3. One proposal and some remarks
1. From Latin adjectives on Contemporary Catalan data to Romance quantifiers

\section{References}

2. New quantifiers in Medieval Catalan

1. We would like to thank the editors of this issue of CJL, Montse Batllori and Maria Lluïsa Hernanz, for their unshakeable confidence in us, and the anonymous Catalan speakers who helped us check the grammaticality of the sentences in Catalan. We are also grateful to Miriam Bouzouita, who reviewed, and undoubtedly improved the English of the original draft of this paper. 


\section{Introduction}

Contemporary Romance languages show a consistent class of determiners. Their most salient distributional property is their prenominal position in which they head nominal expressions in argument positions. This definition assumes the wellknown Determiner Phrase hypothesis which considers this category to be the actual head of the nominal expression it licenses. Whether or not we accept this kind of analysis for traditional NPs, one has to posit a complex structure in order to explain the many different types of determiners we can find to the left of the nominal head in Romance. As Zamparelli (2000) described, we need to distinguish different layers inside the DetP, or as we will call it, the left margin of the NP. Different positions need to be posited for the definite or strong determiners -such as the definite article- and for the indefinite or weak determiners -such as the numerals. The ability to occupy the position provided inside these layers can help us define subclasses of determiners: definite and indefinite articles, demonstratives, possessives, etc.

The subclass of determiners with quantitative meaning, the so-called quantifiers, illustrates the distributional complexity of its word class clearly and, as such, the structure of Romance DetP or the left margin of the NP. Strong quantifiers, such as Catalan tot ('all') or cada ('each'), for instance, need a predeterminer position, the highest layer in the DetP. Weak quantifiers or indefinite ones, on the other hand, remain in the inner layer, which is reserved for the so-called predicative determiners (Eguren \& Sánchez 2003: 115). The comparison between the positions of dues ('two') and altres ('others') in combination with totes, as illustrated in the following examples, reveals the differences between the two subclasses of determiners in Catalan.

(1) a. Totes dues cases em pertanyen.

All two houses me.DAT belong.3pl

'Both houses belong to me.'

b. Totes aquestes altres cases em pertanyen.

All these other houses me.DAT belong.3pl

'All these other houses belong to me.'

But even inside this subclass of indefinite quantifiers we find considerable distributional differences in Romance. Some of them, such as Catalan algun ('some'), remain inside the DP layer and can thus be considered a typical and proper determiner:

(2) Alguns vells amics tenen ja un e-book.

Some old friends have.3pl already an e-book

'Some old friends already have an e-book.'

In (2), alguns is the leftmost constituent of the sentence and precedes as such the nominal expression vells amics, which is headed by alguns and in fact licensed 
as a subject thanks to the presence of this indefinite quantifier. It is thus in complementary distribution with the definite article.

Notwithstanding this, other indefinite quantifiers, such as molt ('many') or poc ('few'), do not behave so consistently. They can appear in the same predicative determiner layer, i.e. between the predeterminer position and the noun:

(3) $\{$ Molts / pocs $\}$ vells amics tenen ja un e-book. \{many / few $\}$ old friends have.3pl already an e-book

' $\{$ Many / few $\}$ old friends already have an e-book.'

In other words, molt and poc seem to be true determiners in (3), and occupy the same position as alguns in (2), licensing a topical NP which functions as the subject of the sentence.

However, we can also find them inside a lower layer of adjectival type, next to the noun head:

(4) Les $\{$ moltes / poques $\}$ i boniques coses que he vist The $\{$ many / few $\}$ and beautiful things which have.1sing seen m' agraden. meDAT like. $3 \mathrm{pl}$

'Those $\{$ many / few $\}$ beautiful things I have seen I like.'

In this sentence molt and poc appear to the right of the determiner les and are coordinated with a qualifying adjective, boniques, which clearly indicates that they must be analyzed in a place lower than the determiner and similar to boniques.

This non-homogeneous behaviour of the Romance quantifiers can easily be explained if we look at their Latin equivalents, which are often adjectives. As is well-known, the history members of the quantifier word class is basically the history of the development of new distributional patterns for the old adjectival word class (Company 1991, 1997; Batllori 1998). The new Romance pattern establishes a new word class, i.e. the determiners, and new subclasses inside it, such as the quantifiers. In other words, the creation of a quantifier position establishes the quantifier word class. This is a long-term process the effects of which can still be seen at work. This development is almost completed in some cases which were already present in Latin or Late Latin, such as algun, or even molt and poc. Other Romance adjectives, such as bastant ('enough') and diversos ('some'), by constrast, have not entirely acquired the quantifier status. Interestingly some contemporary adjectives, such as suficient 'sufficient', have started to develop new quantifierlike distributions, so that they seem to be shifting towards the quantifier word class (Brucart \& Rigau 2002, Camus 2009).

The present paper aims to illustrate the development from adjectives to quantifiers in Romance using the prototypical evolution of indefinite quantifiers from medieval to contemporary Catalan. Section 1 deals with the shift from Latin adjectives to Romance quantifiers and the establishment of a distributional pattern for genuine indefinite quantifiers. By doing so, we can determine how far along the 
way into the new status of quantifier the old adjectives have arrived. Section 2 deals with the appearance of new candidates in the new quantifier class of Old Catalan adjectives. Finally, in section 3 we will try to establish the different stages the Romance adjectives go through in order to accommodate the distributional requirements of the quantifiers and be able to move to this new word class. We will also sketch the contemporary behaviour of the Catalan adjective suficient, which seems to be on its way to becoming a quantifier. We will show how it has achieved some of the typical positions found for the quantitative determiners.

\section{From Latin adjectives to Romance quantifiers}

The first significant characteristic of Latin adjectives with quantitative meaning is their basic distribution. There is no specific position in the Latin NP for this word class as they appear in the same position as any other qualifying adjective, before and after the nominal head or even in non-contiguous positions, as is expected in a non-configurational language, such as Classical Latin (Crisma \& Gianollo 2006, Gianollo 2007). As these authors claim, the distributional properties of Latin adjectives can be explained on the basis of stylistic and literary reasons. This is also the case for those adjectives which later become prototypical indefinite quantifiers in Catalan, such as ALIQUIS, MULTUS, PAUCUS. In examples (5) to (7) (Lewis \& Short 1879), these three adjectives each display a different placement with respect to their nominal head. They can precede it, as in (5a) to (7a), follow it, as in (5b) (7b), or appear separated from it, as in (6c):

a. ex hoc enim populo deligitur aliqui dux, from this indeed people choose.3singPASSIVE some leader (Cic. Rep. 1, 44, 68).

'Indeed it is from among these people that some leader is to be elected.'

b. ...qui censent esse in mentibus hominum tamquam who think.3sing be.INF in mind.ABL men.GEN like oraculum aliquod... (Cic. Div. 2, 48, 100).

oracle some...

'those who think there is some sort of oracle inside the mind of men...'

(6) a. multa acerba [..] habuit ille annus (Cic. Disc. pro Sestio. 27). many bitter had.3sing that year

'There were many bitter things that year.'

b. cum auro argentoque multo legatos Romam mittit (Sall. J. 13, 6). with gold silver-and many ambassadors Rome-to sent 'he sent ambassadors to Rome with gold and silver.'

c. multi fortiissimi viri (Cic. Fam. 5, 17, 3).

many strong.SUPERLATIVE men 'many very strong men.' 
(7) a. paucis diebus post mortem Africani, (Cic. Lael. 1, 3).

few days after death the African.GEN

'a few days after the African's death.'

b. in diebus paucis Chrysis moritur, (Ter. And. 1, 1).

in days few Chrysis died

'after a few days Chrysis died.'

In Late Latin the preference for the prenominal position is already clearly established for those adjectives with a determinative meaning, including the quantitative ones. The situation in the medieval Romance languages can then be seen as a consequence of this growing tendency and Catalan thus does not constitute an exception. In fact, Old Catalan texts show the existence of a new word class with specific distributional characteristics. These features enable us to identify this new quantifier class and to differentiate these quantitative words from the rest of the new Catalan determiners. As we shall see shortly, their distribution is the key to their securing a position of their own inside the left margin of the NP. That said, we should keep in mind that the complexity of the structural layer has been growing since Late Latin, leading to one of the most visible syntactic innovations in Romance (Vincent 1997).

\subsection{The prototypical quantifier distribution: Algun}

As noted above, two different distributional patterns emerged among the Romance quantifiers. First, we can distinguish the subset of universal or strong quantifiers, i.e. the TOTUS class, which has a typical predeterminer distribution. The subset of weak quantifiers of non-universal reference, by contrast, preferred a lower position in the same left margin of the NP, which evolved through the Early Romance period and is manifest in the first Old Catalan texts.

The most representative new weak quantifiers in Old Catalan (and in other western Romance languages) are forms derived from Latin ALIQUIS, that is, alcun / algun 'some'. Old Catalan algun basically has a determinative meaning of a quantitative nature. It represents a quantifier of the existential type, together with un, 'a', from which algun differed by having a greater level of indeterminacy: 'at least one, one or more' and never 'just one', which was the proper value of $u n$.

In line with this determinative meaning, algun had in Old Catalan a clearly defined determiner distribution:

a) It can license a nominal expression by itself, just like an article. It can then occupy the highest and leftmost position inside the NP, preceding as such prenominal adjectives, as in (8a), or any other indefinite determiner, as in (8b). This is the case for any kind of NP, but particularly for the most salient ones, namely topical subjects, where it plays the role of an article, as in (8a): ${ }^{2}$

2. Old Catalan examples are from the Corpus informatitzat del català antic (CICA). 
(8) a. En Ramon de Cardona e alguns richs hòmens de Cathalunya Ramon de Cardona and some rich men of Catalonia cometeren-nos de guerra (Jaume I, Fets: f. 176r, 26). attack.3pl us of war 'Ramon de Cardona and some rich men of Catalonia attacked us.'

b. Axí matex, si li fas mudar alguna altra devoció So if him.DAT make.2sing change some other devotion (Sant Vicent, Sermons IV: 29, 8)

'And also, if you make him change any other devotion...'

b) Algun can also bind a referent in a previous NP and head by itself the corresponding anaphoric NP. As the head of its phrase it appears as a proper pronoun, which always has a human reference and which evolves later on into the exclusive and reduced form algú, as in (9):

(9) mester hi hauria que algú hi resposés (Jaume I, Fets: 187r). necessity there have.3sing that someone there answer.3sing 'it would be necessary for someone to answer.'

Sometimes the indefinite quantifier algun remains in its place while the quantified NP becomes pronominalized by the partitive form en (or the contextual variants $n$ ', ' $n, n e)$ as in (10a), or is completely deleted, as in (10b): ${ }^{3}$

(10) a. E sobre açò ach-n' i alguns qui dixeren (Jaume I, Fets: 101r). and on that had.1sing there some who said.3pl 'and there I had some people who said.'

b. les jens la.n diffamaven [...], que avia fetes mal ses faenes the people her defamed.3pl that had.3sing done wrong her job ab alguns (Clams: 166, 18).

with some 'the people defamed her because she had done a bad job for some of them.'

c) As a nominal head, algun can govern a partitive phrase, i.e. de 'of' + a definite NP in plural, a typical quantitative expression denoting the quantified part of a defined whole:

(11) que abdues les coses pogués demanar si alcuna de les parts that both the things could demand if some of the parties venia contra l' arbitre (Jaume I, Furs: R30, f. 4, 8). come.3sing against the arbitrator 'that he could ask for both things if any of the parties were against the arbitrator.'

3. The pronominal form en appears whenever the original phrase is an internal argument of the verb, as in (10a): the complement of ach 'have'. In all other cases, the quantified noun is deleted, as in (10b). 
d) Algun is never found in adjectival positions, such as nominal predicates, or coordinated with a qualifying adjective. There is, nevertheless, a notorious exception: in Old Catalan algun is also found in postnominal positioning following the nominal head:

(12) Amich, no m'ajusté ne m'acosté

a neguna fembre,

Friend, not me-join.1sing nor me-approach.1sing to any woman ne fiu mal ne desplaer a home algun. (Exemples: 6, 31). nor made.1sing evil nor upset to man some

'My friend, I did not join or approach any woman nor did I cause any evil or upset to any man.'

This diverging distribution, which seems to be an obvious remnant of the Classical Latin syntax of ALIQUIS, has nonetheless considerable constraints and a different interpretation. Postnominal algun is a polarity item, so it can only be found in modal or negative contexts, like the one given in (12). As such, its meaning is always determined by the type of polarity context to which it belongs. In (12), for instance, it is equivalent to a negative quantifier, not to an existential one. In view of this, it seems more suitable to consider this postnominal algun separately from the canonical algun, which has a prenominal distribution (Pérez Saldanya 2004).

If we then disregard the postnominal use of algun, we can state that algun has achieved since the early Middle Ages all the characteristics of a typical quantifier. As we will see below, other indefinites such as molt and poc are still far from achieving the same homogeneity with respect to their word class membership.

\subsection{Other quantifiers}

The rest of the Old Catalan indefinite quantitative words can be classified, together with alcun / algun, as determinative quantifiers, whenever we find the same distributional pattern. Consequently, molt and poc can be regarded as members of the same class, inherited from Latin adjectives. Their meaning is also of quantitative nature: they define an amount of individuals or properties the limits of which are not explicitly defined but are somewhat broad in the case of molt (a multal quantifier) and somewhat narrow in the case of poc (a paucal quantifer). However, their syntactic behaviour presents significant differences.

First of all, molt and poc share with algun the first three syntactic characteristics (a) to (c) listed in section 1.1. However, they present a fourth one (d) which is not available for existential quantifier:

a) They can govern nominal expressions, including topical preverbal subjects, and need not be accompanied by another determiner: 
(13) a. enaxí con si molta gent hi entràs e per la pressa la $\cdot$ I. so as if many people there enter.3sing and by the hurry the one casegués sobre 1' altre (Diàlegs: f. 69v, 24).

fall.3sing over the other

'as if many people were to enter there and were to fall over each other due to their hurry.'

b. E quasi aquell dia poca gent restà en lo camp que And almost that day few people stayed.3sing in the field which no fos tota al palench. (Martorell, Tirant: 1113, 25). not be.3sing all in the palisade 'And that day there were few people in the field outside the palisade.'

b) They can also head NPs by themselves as proper nominal heads, as in (14a), or as pronominalized substitutes for previous nouns, as in (14b):

(14) a. Molts $\quad e$ moltes són així malefficiats que jamés [..] ManyMASC and manyFEM be.3pl so cursed that never no.s poden carnalment acostar (Dotzè: 158, 17). not-them can.3pl carnally approach.INF 'Many men and many women are so badly cursed that they cannot have sexual relations.'

b. [del sepolcre de sant Andreu ix manna $_{\mathrm{i}}$, $] \ldots$ cor from-the tomb of Saint Andrew com.3sing manna so that si n'ix poca $_{i}$, demostra que la terra levarà if come.3sing out a little demonstrate.3sing that the land grow.3sing poc fruyt (Vides: 36, 3).

few fruit 'manna comes out of Saint Andrew's tomb ... if just a little [manna] comes out, it will mean that the land will yield little.'

c) Molt and poc can also be the head of partitive phrases:

(15) a. Molts dels nostres s'animaren, e s'endreçaren many of the ours them-cheer.3pl up and them-begin.3pl d'armar (Epistolari Ia: 41, 22).

of armINF 'many of our men cheered up and began to arm themselves.'

b. e axí que pochs dels seus la possehyren and so that few of the theirs her.ACC possess.3pl aprés (Dotzè: 19, 16).

afterwards 'and a few of their men had her afterwards.' 
d) Finally, molt and poc can also function as degree adverbs. In contrast to algun, both molt and poc inherited from Latin an adverbial homonymous counterpart that served as a degree quantifier and that, as we will see later on, seems to be another striking property of the Romance quantifiers:

(16) a. E axí fo bé muylerat de dona molt noble et molt richa and so be.3sing well married of woman very noble and very rich (Muntaner, Crònica: f. 160ra, 5).

'And so he was married to a very noble and rich woman.'

b. dix que poc abans de Nadal proppassat se.n vingué told.3sing that a little before of Christmas past him-came3sing en aquesta ciutat. (Lleida IIc: f. 26r, 34).

in this town

'he said he arrived in town not long before Christmas.'

Although these four distributional characteristics seem to clearly identify molt and poc, already in Old Catalan, as proper determiners of the weak quantifier type, they also present some other properties that cast some doubt on their final classification, namely:

e) They do not always occupy the highest and leftmost position inside the NP. Sometimes molt, and more often poc, appear to be in an adjectival position rather than a determiner one. For instance, we can find them to the right of the indefinite altre ('other'):

(17) a. Aprés venien martes, apòstols, confesors e altres molts afterwards came.3sing martyrs apostles confessors and other many sants (Antiquitats I: 46, 14). saints

'Afterwards martyrs, apostles, confessors and many other saints came.'

b. E sapiau que -ls dimonis estan en l' ayre, and know.IMPERATIVE2pl that the devils be.3pl in the air sinó huns pochs.

but some few

que n'ha ací en lo món, e altres pochs en infern

that have.3sing here in the world and other few in hell (Sant Vicent, Sermons IV: 262, 18).

'You must know that the devils are in the air, except for a few who are here on earth and a few others in hell.'

In fact, poc, when appearing prenominally, seems to be placed most often in the same slot as prenominal adjectives. Thus, we find it to the right of other determiners, such as the definite and the indefinite articles, as in (18) (see also the first instance of pochs in (17b)), and also following other quantifiers, as in (19): 
(18) a. la clartat del sol enfosqueeix los pocs lums de les esteles the brightness of the sun darken.3sing the few lights of the stars e dels focs and of the fires (Vides: 207, 25). ${ }^{4}$

'the brightness of the sun darkens the few lights of the stars and the fires.'

b. E cor vesien unes poques olives en los arbres del monestir and because see.3pl some few olives in the trees of the monastery (Diàlegs: f. 9r.27).

'and because they saw a few olives in the trees of the monastery...'

(19) alcunes poques coses era forçat d'etorgar de ço que fet some few things be.3sing obliged of-give of that that done avia

have. 3 sing

(Diàlegs: f. 58v.9).

'he was obliged to admit a few things out of those he had done.'

The same adjective-like behaviour can be discerned if we examine other syntactic positions of Old Catalan molt and especially poc:

f) They can appear coordinated with qualifying adjectives, thus occupying exactly the same position:

(20) a. per[què] no fos pres per lo dit procés de absència in order not be.3sing taken because the said trial of absence e altres molts e enormes crims (Epistolari, IIc: 141, 32). and other many and huge crimes 'in order not to be imprisoned because of that trial in absentia and many other great crimes.'

b. segons la quantitat del preu sie poc o gran depending the quantity of the prize be.3sing few or big (Jaume I, Furs: R. 27 F. 2, 2). 'depending on the price, be it small or large.'

g) They can also occupy the canonical position of adjectives in Romance, that is, they are sometimes placed to the right of the noun with which they appear:

4. We also have the same distribution with the definite article for molt, but it seems to reflect a Latin influence in 16 th century Renaissance texts. 
(21) a. se'n portaren [...]e d' altres robes moltes e una lansa them-take.3pl and of other clothes many and a lance (Clams I: 115, 11).

'they took away many other clothes and a lance.'

b. Car per amor les coses poques creixen (Malla, Memorial: 191, 32). but because love the things few grow.3pl 'because of love small things grow.'

h) Both molt and poc can also be found in definite constructions with lo, i.e. the old masculine form of the article. The complement of $l o$ in these constructions with abstract and intensive meaning is typically a qualifying adjective (i.e. lo bo 'the good things'):

(22) a. car no puch yo, per lo molt que só amat but not can.1sing I because theNEUT many that be.1sing loved (Alegre, Somni: 17, 30).

'but I cannot, because of how much I am loved.'

b. ahont és de creure que fóra trobat lo poc que de hence be.3sing of thinkINF that be.3sing found the few that about les coses haurien escrit (Despuig, Col-loquis: 179, 17). the things have.3pl written 'that is why we think the little that they must have written was found.'

i) They can head nominal predicates in attributive sentences:

(23) a. E les demandes foren moltes (Jaume I, Fets: f. 168r, 23). and the demands be.3sing many 'and the requests were many.'

b. cor lo loc era poc (Diàlegs. f. 53v, 15). but the place be.3sing few 'but the place was small.'

It should be noted that, for these preceding four contexts, the meaning of these words is clearly not quantitative but rather of a qualifying and predicative nature. Molt seems to mean 'abundant' or 'numerous' and poc is definitely 'small'. This is what we also find in the following two contexts:

j) Poc, but not molt, can be preceded, and thus quantified, by degree adverbs, just like any other qualifying adjective:

(24) l' altre és peccat per massa poca quantitat the other be.3sing sin for too much little quantity (Llull, Cavalleria: 215, 4).

'the other one is a sin for too small a quantity.' 
k) And, finally, they can appear with intensive (-íssim) or diminutive (-et) morphology, which is not compatible with a determiner meaning:

(25) a. Vingueren-me a veure moltíssims cavallers los tres come.3pl -me.ACC to see.INF many-SUPERLAT gentlemen the three primers dies que arribí a València (Valeriola, Biografia: 185, 26). first days that arrived.1sing to Valencia

'Many, many gentlemen came to see me during the first three days after I arrived in Valencia.'

b. vostra mercé solament aurà perdut aquestos poquets dies your mercy only have.3sing lost these few-DIM days (Liori i Requesens, Epistolaris: 142, 25). 'you will only have lost these few days.'

Some of these adjective properties, like the postnominal distribution in $\mathrm{g}$ ), are lost in the shift to Contemporary Catalan but most are still present. They can probably be explained as remnants of the original syntax of the Latin adjectives MULTUS and PAUCUS. It may also be the case, however, that this kind of vague quantifier had more in common with qualifying adjectives than existential quantifiers in terms of denotation and content. Their fuzzy limits and hence the subjectivity of their reading can help to understand the behaviours like those exhibited in (24) (25). It is a fact that molt and poc seem to be available in two different places within the NP in Old Catalan: not only can they be determiners like algun, that is, weak quantifiers with a determinative meaning, but they can also be pre- or postnominal adjectives, like the ordinal numbers and display thus basic attributive meaning.

Besides the inherited algun, molt and poc, the class of weak quantifiers in Old Catalan is completed with three other invariable and non-inflected words: prou and assats ('enough'), and massa ('too much'). Their Latin antecedents are not, as in the case of molt and poc, adjectives. Prou proceeds from the Vulgar Latin form PRODE, from PRODEST 'it helps' and hence 'it is sufficient'. Assats, also present in French, Occitan and Italian, is a Romance formation out of a Latin adverbial expression AD SATIS 'in a sufficient way, enough'. Massa is, by contrast, a Catalan specific quantifier, made out of the Latin noun MASSA 'dough', and also 'mass', possibly through an adverbial expression meaning 'massively, in a huge quantity'.

The non-adjectival origin of prou, assats and massa explains their syntactic distribution in Medieval Catalan, which is different, from that of the other weak quantifiers algun, molt and poc, as we will show below:

a) The three quantifiers can function as determiners and head NPs, as in (26a) and (26b). That said, it is not easy to find medieval examples in which they can license the subjects in topic position, as in (26c), a case with a postverbal subject of an unaccusative verb appears: 
(26) a. Prou paraules haveu despés (Martorell, Tirant: 325, 21).

Enough words have.2pl wasted

'You have wasted enough words.'

b. a. lo qual ja havia fetes assats armes (Curial: 188, 22). who already have.3sing done enough arms

'who had already fought enough.'

c. Quant ix massa sanch del nas e ven per when come.3sing out too much blood from the nose and comes for terme... (Avicenna, Cànon: f. 29v, 18).

end...

'when too much blood is coming out of the nose and ceases...'

b) Prou and assats can also bind NPs, and once again it is not easy to find good examples for this anaphoric role:

(27) a. E son cert que són prou d' aquests qui s'ardirian and be.1sing certain that be. $3 \mathrm{pl}$ enough of these who them-dare de negar asò (Corbatxo: 41, 3).

of denyINF that

'And I am certain that there will be enough of those who dare to deny that.'

b. Gran fon la batalla e $n$ 'i moriren assats

Great be.3sing the battle and there die $3 \mathrm{pl}$ enough

(Gorigós, Flor: 113, 26).

'The battle was great and quite a few men died.'

c) The ability to head partitive constructions does not seem to be easily available for these quantifiers and we have encountered only very few examples:

(28) a. que assau de aquelles persones [...]hagueran per ferm que... that enough of those people have.3pl for certain that (Corbatxo: 75, 18).

'that quite a few of those people were certain that...'

b. són estats prou de aquells que n'an trobades les dones be. $3 \mathrm{pl}$ been enough of those who have.3pl found the women bones (Flors: 76, 22).

good

'there have been plenty who have found good women among those people.'

d) And finally, the three of them had adverbial homonyms as degree adverbs: 
(29) a. si no és prou estret lo axerop, treurets -lo if not be.3sing enough thin the syrup get.IMPERATIVE out it del pot (Confits: 281,8).

of the pot

'if the syrup is not thin enough, get it out of the pot.'

b. De açò scrivim assats congoxosament al dit senyor about that write1pl enough sadly to the said sir (Epistolari IIa: 25, 20).

'we wrote about this rather upset to the aforementioned gentleman.'

c. tolre tota vexació e despesa, scàndels e perills, remove.INF every humiliation and expense scandals and dangers que són massa apparellats (Epistolari, Ie: 30, 24).

that be.3pl too paired

'to remove every humiliation and expense, scandals and dangers, which are always too close.'

In view of the above, we can conclude that, these three forms behave consistently as quantifiers when heading certain non-salient NPs, as in (26a)-(26b). In other positions, on the other hand, they do not seem to exhibit the characteristics of a quantifier. Again, as is the case for molt and poc, this might be due to the etymology of these words, since they each derive from some kind of adverbial expression. This could explain not only the difficulties that they have functioning as nominal quantifiers, but also their full adaptation to the role of degree adverbs, as shown in (28). Due to the non-prototypical status of these words, they suffer the rivalry of new forms and, as a consequence, assats is later replaced by the adjective bastant, a Romance example of the word class change we have already mentioned for the Latin adjectives and which will be the topic of the next section. ${ }^{5}$

\section{New quantifiers in Medieval Catalan}

In Catalan, as in other Romance languages, the medieval inventory of indefinite weak quantifiers underwent modification during the late Middle Ages. As noted above, even one of the old elements, assats, began to disappear from the written language. Other words were redefined in order to enter this new class. This was the case, for example, of the adjective bastant 'sufficient, appropriate', an old present participle, and the ordinary qualifying adjective diversos 'varied, assorted, different'.

In Modern Catalan, bastant and diversos tend to be classified as weak quantifiers in current reference grammars (Brucart - Rigau 2002; DIEC2: s.v. divers).

5. As an anonymous reviewer has pointed out, there is another factor which explains the peculiar distribution of this subgroup of quantifiers. They prefer non-specific interpretation, a reading which is incompatible with topic NPs or partitives. Interestingly enough, bastant, which partially replaces assats (and prou), behaves similarly in Contemporary Catalan. 
Nevertheless, they display quantitative content, although they do not appear in all the contexts in which the original quantifiers shown in 1.2 are found, as we will show below. This incomplete development might explain, for example, why diversos is not accepted in partitive structures but works perfectly well as a complement of measure verbs. It seems to have full quantitative meaning but only partially the corresponding syntactic properties of quantifiers. ${ }^{6}$

\subsection{Bastant and diversos as adjectives}

The Old Catalan words bastant and divers originally worked as qualifying adjectives. Their meaning is far from being quantitative or even determinative. We find some equivalents within this group of adjectives; suficient and capaç, for instance, are good synonyms for bastant, as are vari, distint and diferent for divers. As is usual in the medieval literature, these adjectives often form synonymic coordinated expressions, such as bastant e suficient and diversos e diferents.

The placement of these adjectives is also fully consistent with the other members of their word class. Only bastant shows some peculiarities due to its origin as a present participle, i.e. it is often accompanied by the same prepositional complements $a$ 'to' or per 'for' which appear with the cognate verb bastar 'to suffice' (see below (30a) and (32a)). But apart from this, bastant and divers show typical adjectival placement:

a) They are usually placed to the right of the noun they qualify, as in (29), so they occupy the position of a qualifying adjective:

(30) a. no ha [...] collites d' esplets e criances de bestiars bastants a not have.3sing crops of goods and raisings of animals sufficient to sa provisió (Epistolari València I, 4/5 27, 5).

their supply

'there are no sufficient crops nor animals for their supply.'

b. per lo qual en les coses vivents vénen corrupcions e morts for which in the things living come.3pl corruptions and deaths soptanes e malauties diverses en alcunes determenades regions sudden and diseases different in some determined regions (Agramont, Regiment: 54b, 25).

'this is why living things develop deficiencies, sudden deaths and various diseases in certain regions.'

b) As noted above, they appear in coordination with other qualifying adjectives:

6. In order to have an idea of the current usage of diversos we carried out an informal survey of native Catalan speakers from different areas of the linguistic domain. The results point clearly in the direction just described: diversos can easily appear in contexts where a quantitative meaning is needed. However, it is rare in some of the typical quantifier positions, such as the partitive ones. 
(31) a. e que nós façam axí ferms e bastants privilegis and that we do.1pl so solid and sufficient privileges (Girona IIb: 344, 25).

'so that we shall grant solid and sufficient privileges.'

b. entre diversese poderoses persones (Epistolari, Ib: 133, 5). among varied and powerful persons 'among varied and powerful people.'

c) As regular adjectives they can head nominal predicates:

(32) a. qui és bastant a loar la justícia de nostra Dona? who is sufficient to praise the justice of our Lady (Llull, Santa Maria: 150, 21).

'who is sufficient to praise Our Lady's justice?'

b. Hon cascú membra, segons que és divers a l' altra, Thereforeevery member because be.3sing different to the other ha mester diversa cura (Llull, Doctrina I: 206, 18). need.3sing different cure 'therefore every limb, since it is unique, requires a different cure.'

d) They can be modified by degree adverbs, like any other qualifying adjective:

(33) a. Los moros foren contents de dar lo salvoconduyt the Moors were.3p satisfied of give.INF the safe-conduct tant bastant com lo volgueren. (Martorell, Tirant: 125, 2). so sufficient as it wanted.3pl

'The Moors were happy to give the safe-conduct that would suffice for whatever they wanted.'

b. Los tartres són molt diversos de les altres gents, the Tartars be. $3 \mathrm{pl}$ very different of the other people de manera i de custums (Gorigós, Flor: 120, 12). of manner and of habits

'The Tartars are very different from other people in manners and habits.'

e) They can display intensive morphology:

(34) me feren un bastantíssim poder meACC made.3pl a sufficientINTENSIVE power (Valeriola, Biografia: 146, 9). 'they gave me a truly sufficient power.'

f) And finally, similarly to qualifying adjectives, they have adverbial derivatives in -ment: 
(35) a. si doncs no.s prova en altra manera

if then not-it prove.3sing in another way

bastantment (Jaume I, Furs: R62, F3, 5).

sufficiently

'unless it is proved sufficiently in another way.'

b. Tu, Senyor, nos has diversament flagel-lats

You Lord us have.2sing differently flagellated

e per moltes vies (Dotzè: 227, 14).

and through many ways

'You, Lord, have flagellated us in various and many ways.'

As can be seen, the early Catalan texts up to the $15^{\text {th }}$ century prove beyond doubt the adjectival status of the two words under discussion. Notwithstanding this, a change started to take place around the mid 14th century, as we will explain in the following section.

\subsection{New distributional patterns for bastant and diversos}

Beginning in the late 14th century, both bastant and the plural form diversos acquired new distributional possibilities that brought them closer to indefinite weak quantifiers. Interestingly, the shift was a gradual one, with each word moving to its new identity at its own speed. Some quantifier characteristics appear very soon, such as the prenominal placement. Others, on the other hand, appear later or are still shifting. Yet others do not seem to be acquired yet, as is the case for the ability to head partitive constructions. In the following we will discuss this in more detail.

a) Prenominal placement: The adjectives under discussion have been able to appear before the noun quite early on. This is not at all surprising, since many other qualifying adjectives can appear in this position in the Romance languages. These so-called prenominal adjectives include ordinal numbers and qualifying adjectives such as gran. This prenominal position most probably induces a slight change in meaning by adding some more information to identify the noun's referent (Demonte 1999: 194-195). This is relevant if we bear in mind the current meaning of bastant and diversos:

(36) a. que no és bastant memòria de hòmens

tha not be.3sing sufficient memory of men

a recordar -ho (Curial: 306, 7).

to rememberINF it

'that there is not sufficient memory in men to remember it.'

b. paria [...] sentís udolaments de diversos animals (Corbatxo: 16, 7). seemed.3sing hear.1sing cries of varied animals

'It seemed I could hear cries of various animals.' 
b) In this prenominal position they can govern the whole NP on their own and the old qualifying meaning becomes less relevant. A new quantitative meaning — 'enough' for bastant and 'some' for diversos — seems possible for examples like the following, which date from the late $14^{\text {th }}$ century:

(37) a. E sobre les dites coses ha dades bastant fermança and over the said things have.3sing given enough strength (Epistolari Id: 25,11)

'and about the aforementioned, he has given enough firmness.'

b. $\mathrm{Si}$ en imfern ha .I. foc ho diverses focs

whether in hell have.3sing one fire or some fires

(Diàlegs: f. IVr, 1).

'whether there is one fire or more in hell.'

It should be noted that diversos in (37b) is coordinated with a numeral, thus forcing a quantitative interpretation. The original meaning, to wit 'different', seems thus unlikely in this context.

c) The plural form of diversos begins to appear soon after at the leftmost position of the phrase, preceding other prenominal adjectives, as in (38a). From the moment it also appears before other determiners such as the indefinite altre 'other' (38b) or possessives (38c), we can claim that it is placed in a determiner position. An example from the mid 15 th century (38d) where diverses is coordinated with the numeral quantifier una 'one' confirms this assumption:

(38) a. e féu fer en cascun loch fort diversos and made.3sing makeINF in every place strong some grans graners (Dotzè: 296, 1)

big barns

'and he ordered built in every garrison some big barns.'

b. los quals patis se poden trencar si ells entren en orde [...] agreements them-can.3pl breakINF if they come in order o per diversos altres cassos (Dotzè: 370, 9).

or because of some other reasons

'agreements that can be broken if they take holy orders or for various other reasons.'

c. Per diverses nostres letres vos havem scrit, pregant-vos...

by some our letters you have.1pl written begging you

(Girona IIe: 563, 11).

'We have written you various letters, begging you.'

d. E pregà.m molt que us suplicàs, una $e$ diverses voltes, and asked.3sing-me much that you beg.1sing one and some times que... (Martorell, Tirant: 1331, 17).

that

'And he asked me many times to beg you that...' 
In the case of bastant the movement towards determiner status is slower. ${ }^{7}$ During the last centuries of the Middle Ages it could only govern postverbal constituents, never subjects. It thus does not appear to the left of any other adjectives and of course never precedes any determiner. Orders like bastants altres, where bastants is clearly placed in a determiner position, higher than altres 'others', only appear in Contemporary Catalan:

(39) En aquest cas de Quartonda, com en bastants altres, es pot in this case of Quartonda as in enough others it-can.3sing comprovar... (N. Gómez i Serrano, De paleotoponimia..., 1949. CTILC). checkINF 'in the case of Quartonda, as in many others, it can be confirmed...'

d) Diversos, by contrast, seems to be available in prenominal subject position early on. Nevertheless, examples such as (40) are not frequent in medieval texts. They are found abundantly only in recent centuries, being well established by the first half of the $19^{\text {th }}$ century, as the texts in the CTILC confirm:

(40) No és dupte que diversos altres sants no hagen fetes moltes not be.3sing doubt that some other saints not have.3pl done many altres semblants e majors abstinències (Dotzè: 293, 23). other similar and greater abstinences

'There is no question that various other saints have performed many other similar and greater abstinences.'

Bastant, as noted, once again shows a slower development. Topical subjects governed by this quantifier are not firmly established in the written language until the first decades of the last century. As explained in footnote 4, the preference for non-specific contexts must have played some role in this:

(41) que bastants d'aquestes petites tuberculosis de cadera [...], that enough of these little tuberculoses of hip tal vegada haurían pogut curar per l' immovilisació may be habe.3pl been able cureINF through the immobilization (G. Estapé, Treballs quirúrgichs, 1909. CTILC).

'that quite a few of these little nodules in the hip could have healed through immobilization.'

e) Diversos can also be found as a pronoun in a text by Antoni Canals from the first quarter of the $15^{\text {th }}$ century:

(42) e com és soptill en saber enganar diverses

7. It is the same in Spanish, where the equivalent bastante has evolved very slowly towards quantifier status (Camus 2008). 
and how be.3sing subtle in knowINF fool some

(Canals, Confessió: f. 19va, 7).

'and how capable he is of fooling someone.'

This usage, although not frequent, also appears in the contemporary language, as is shown below in example (44b). The pronominal use of bastant is again a late development. The first attestations in the written language (CTILC) go back to the $19^{\text {th }}$ century, as can be seen in the following sentence:

(43) las òrdas d'el Rèi já no son bastánts per refrenar the hordes of-the king already not be.3pl enough to holdINF back

l' alborót (A. Febrer, Daniel..., 1836. CTILC).

the commotion

'the king's hordes are not enough to hold back the commotion.'

f) None of these words are found in the partitive construction until the last hundred years, when we find some scattered and dubious examples such as the following: ${ }^{8}$

(44) a. podem dir que la normativa actual, en bastants dels seus can.1pl sayINF that the rules current in enough of its punts no assoleix l' eficàcia points not achieve.3sing the efficiency (L. Polanco, La normativa al Pais Valencià, 1984. CTILC). 'it could be said that the current set of rules does not achieve effectiveness in many of its sections.'

b. y mentres en la Convenció federal y en las dels and while in the convention federal and in those of-the diversos dels Estats... (V. Almirall, Lo catalanisme, 1886. CTILC). some of-the States

'and meanwhile in the federal Convention and in those of the various States...'

g) Finally, the original adverb in -ment, which is associated with a qualifying meaning, disappears and is substituted by a homonymous form. This change only takes place in the case of bastant but not before the $18^{\text {th }}$ century:

(45) Es bastant dificil fer entendre als pobres que... be.3sing enough difficult makeINF understandINF to-the poors that (J. Batista Foix, Instruccions generals..., 1834. CTILC).

'It is quite difficult to make poor people understand that...'

8. As claimed above, current speakers of all varieties of Catalan tend to consider this kind of structure ungrammatical, at least in the case of diversos. Therefore, we infer that diversos is not yet possible in partitive contexts. 
By contrast, diversos did not develop a degree adverb. We should keep in mind that this word is similar to algun in meaning and that this last form never had any homonymous adverb either. The old adverb diversament did not disappear and corresponds to the homonymous original adjective divers, 'varied, different'. This qualifying and fully inflected adjective has survived to the present time side by side with the quantifier-like diversos, which only displays a plural form. This inflectional reduction is another new characteristic of this word acquired on its way to the new word class.

This long evolution also includes the loss of some of the previous adjectival properties. In current Catalan it is no longer possible to modify these words by means of a degree adverb, as is possible in Old Catalan (see (33)). Intensive forms like bastantíssim disappear along with the old bastantment. The final result seems to be an increasing connection of both diversos and bastant to the same group of weak or vague quantifiers that includes molt and poc (Sánchez López 1999: 1036-1037; Gutiérrez Rodríguez 2006). They are also available in two different places of the NP, i.e. either as determiners, like algun, or as adjectives, like the prenominal adjectives.

\section{A proposal and some remarks on data from Contemporary Catalan}

\subsection{A path towards the status of quantifier}

In view of the data regarding the evolution from Latin adjectives MULTUS / PAUCUS to Old Catalan quantifiers molt / poc and from Old Catalan adjectives bastant / divers to Contemporary Catalan weak quantifiers bastant / diversos, it is of interest to sketch an ordered list of syntactic characteristics in order to establish a possible pathway of the word class change we are examining. The following steps represent the consecutive milestones in the evolution of these words from adjectives to quantifiers in Romance:

1. They increasingly show prenominal placement, with its respective consequences for the original descriptive or attributive meaning. The original qualifying adjective can be grouped with other prenominal adjectives and develops referentiality-oriented content.

2. When prenominal, these adjectives appear at the leftmost position of the NP, without determiners, thus governing this constituent by themselves. As a consequence, the quantitative meaning is reinforced and becomes preferable in this position.

3. They start to appear to the left of other prenominal adjectives. This raising movement towards a higher syntactic position goes on by passing over to the left of indefinite or possessive determiners. At least in these occurrences, their place in the left margin of the NP corresponds to that of proper determiners.

4. As a final confirmation of this new syntactic position, they begin to head topical subjects, that is, to carry out the same function as any genuine determiner such as articles and demonstratives. 
5. Like most of the Romance determiners, they can act as pronouns and thus bind a referent in a previous NP.

6. A homonymous degree adverb is developed to serve as a quantifier in contexts other than nominal ones. This is a very common feature in the case of Romance quantifiers, particularly for those with evaluative content, such as Catalan molt, bastant, massa, poc, etc.

7. And as the final and crucial step, the pronominal distribution gives way to the most specific feature of Romance indefinite quantifiers, to wit, their ability to head partitive constructions. The fact that it takes a long time for this to appear suggests it is the defining trend of this class of determiners. Once old adjectives acquire it, they should be considered canonical quantifiers.

When all these stages have been achieved the word class change is complete. This process is usually accompanied by the loss of the most salient adjectival features that the word previously possessed, such as the forms ending in -ment, and the intensive and diminutive morphology. These do not always disappear completely, as we have seen for the case of the new Catalan quantifiers. Having said this, some of these remaining properties do not show up frequently and become secondary or rare with respect to the new properties.

The picture we have just sketched for development of Romance quantifiers out of adjectives can be easily tested. As mentioned in the first paragraphs of this paper, the same kind of word class changes are now taking place in Catalan, as we will briefly discuss in the next section.

\subsection{Suficient in Contemporary Catalan}

The word suficient 'sufficient' in Contemporary Catalan behaves regularly as an ordinary adjective. It appears to the right of the noun it modifies and can be coordinated with other qualifying adjectives:

(46) Disposem

d' informació ordenada, clara $i$ suficient. have.1pl at our disposal of information ordered, clear and sufficient 'We have at our disposal orderly, clear and sufficient information.'

Nevertheless, this word has some obvious overlaps with indefinite quantifiers, especially with bastant and prou. First of all, its meaning is very close to these evaluative words. There are, however, some additional overlaps which point to a word class shift:

a) It usually has a prenominal distribution:

(47) No té

la suficient autoritat.

not have. 3 sing the sufficient authority.

'He does not have sufficient authority.' 
b) It can even occupy the leftmost position of the NP, without determiners, and govern it:

(48) Té suficients diners per comprar-la. have.3sing enough money to buy it 'He has enough money to buy it.'

Nonetheless, although it can head postverbal subjects (49a), suficient cannot license this constituent when it is in a topic position, that is, when it is preverbal (49b). So it cannot replace the definite article:

(49) a. En el debat intervindran suficients persones. in the debate intervene.3pl enough people 'Enough people will participate in the debate.'

b. *Suficients persones intervindran en el debat. enough people intervene.3pl in the debate 'Enough people will participate in the debate.'

c) Its original adverbial counterpart in -ment (suficientment) is often replaced by a new homonymous adverbial form. It is already a proper degree adverb that can be found not only in the current spoken language but also in the written language since the early $20^{\text {th }}$ century:

(50) a. i va combatre el projecte [...] per no deixar suficient and fought.3sing the project because of not leave enough garantitzats els drets del ciutadà. guaranteePART the rights of-the citizen (G. de Brocà, Biografia de R. L. de Dou..., 1916. CTILC). 'and he fought against the project because it did not sufficiently guarantee the citizens' rights.'

b. Sou vosaltres suficient llests per a capir be.2pl you enough clever to understand (J. Mascarell, Amics de muntanya..., 1961. CTILC). 'You are clever enough to understand.'

As we have shown, contemporary suficient has achieved some of the new features proposed in this paper and is on its way to becoming a weak quantifier. Other features have not been acquired yet, namely the most salient ones. As seen in example (49b), suficient cannot head and govern preverbal subjects. Neither can suficient bind a previous NP, that is, it has not yet developed pronominal functions: 
(51) a. *Van assistir moltes persones ${ }_{i}$ a la festa $i$ en vaig saludar attended.3pl many people to the party and met.1sing suficients . $_{\text {. }}$ enough 'Many people attended the party and I met quite a lot of them.'

b. *Van assistir moltes persones ${ }_{\mathrm{i}}$ a la festa $\mathrm{i}$ vaig parlar amb attended.3pl many people to the party and spoke.1sing with suficients . enough

'Many people attended the party and I spoke with quite a lot of them.'

Additionally, it is far from achieving the last property, that is, the ability to head partitive constructions, which we defined as the most idiosyncratic property of the quantifiers:

(52) Vaig parlar amb *suficients dels assistents. spoke.1sing with enough of-the attendees. 'I spoke quite a few of the attendees.'

It seems then that the adjective suficient cannot be considered a quantifier yet, even though it has already completed some of the stages of the word class change suggested in section 3.1. The first steps in the list have already been undergone, similarly to the case of bastant and diversos. It remains to be seen if the final stage will be the development of a partitive construction, as has been the case for those words.

\section{References}

Batllori, Montse (1998). «Naturaleza y distribución de los determinantes y modificadores nominales en las lenguas románicas». In: Sintassi storica. Atti del XXX Cogresso della Società di Lingüística Italiana. Roma: Bulzoni, pp. 549-566.

Brucart, Josep M.; Rigau, Gemma (2002). «La quantificació». In: Solà, Joan; Lloret, Rosa Maria; Mascaró, Joan; Pérez-Saldanya, Manuel (dirs.). Gramàtica del català contemporani. Barcelona: Empúries, vol. 2, pp. 1519-1589.

Camus, Bruno (2005). «La quantificació: estudi comparatiu castellà-català». Caplletra 38: 101-118.

Camus, Bruno (2008). «De adjetivos a cuantificadores: Un fragmento de la historia de los indefinidos románicos». In: Olza Moreno, Inés; Casado Velarde, Manuel; González Ruiz, Ramón (eds.). Actas del XXXVII Simposio Internacional de la Sociedad Española de Lingüística. Pamplona: Servicio de Publicaciones de la Universidad de Navarra, pp. 87-95. http://www.unav.es/linguis/simposiosel/actas/

Camus, Bruno (2009). «Cuantificadores I. Los cuantificadores propios». In: Company Company, Concepción (dir.). Sintaxis histórica de la lengua española. Parte II: La frase nominal. México: FCE, UNAM, vol. 2, pp. 881-962.

Company Company, Concepción (1991). La frase sustantiva en el español medieval. Cuatro cambios sintácticos. México: UNAM. Instituto de Investigaciones Filológicas. 
Company Company, Concepción (1997). «Prototipos y el origen marginal de los cambios linguiísticos. El caso de las categorías del español». In: Company Company, Concepción (ed.). Cambios diacrónicos en el español. México: UNAM, pp. 143-168.

Corpus informatitzat del català antich (CICA). Joan Torruella in collaboration with Manuel Pérez Saldanya (UV); Josep Martines; Vicent Martines (UA), http://lexicon. uab.cat/cica.

Corpus textual informatitzat de la llengua catalana (CTILC). Institut d'Estudis Catalans, http://ctilc.iec.cat/.

Crisma, Paola; Gianollo, Chiara (2006). «Where did Romance N-raising come from? A parallel study of parameter resetting in Latin and English». In: Doetjes, Jenny; González, Paz (eds.). Romance Languages and Linguistic Theory. Selected Papers from 'Going Romance' 2004. Amsterdam: Benjamins, pp. 71-93.

Demonte, Violeta (1999). «El adjetivo: Clases y usos. La posición del adjetivo en el sintagma nominal». In: Bosque, Ignacio; Demonte, Violeta (dirs.). Gramática descriptiva de la lengua española. Madrid: Espasa-Calpe, vol. 1, pp. 129-215.

Eguren, Luis; Sánchez López, Cristina (2003). «La gramática de otro». Revista Española de Lingüística 33: 69-122.

Gianollo, Chiara (2007). «The Internal Syntax of the Nominal Phrase in Latin. A Diachronic Study». In : Purnelle, Gerald; Denooz, Joseph (eds.). Ordre et cohérence en Latin. Liège: Université de Liège / Librairie Droz, pp. 65-80.

Gutiérrez Rodríguez, Edita (2006). «Bastantes no siempre son suficientes». In: Villayandre, Milka (ed.). Actas del XXXV Simposio Internacional de la Sociedad Española de Lingüística. León: Universidad de León. http://www3.unileon.es/dp/ $\mathrm{dfh} / \mathrm{SEL} / \mathrm{actas} . \mathrm{htm}$.

Institut d'Estudis Catalans (2007). Diccionari de la llengua catalana, segona edició (DIEC2). http://dlc.iec.cat/index.html.

Lewis, Charlton T.; Short, Charles (1879). A Latin Dictionary. Oxford: Clarendon Press. http://www.perseus.tufts.edu/hopper/text?doc=Perseus:text:1999.04.0059.

Pérez Saldanya, Manuel (2004). «La negació i la concordança negativa en català antic». Estudis Romànics 26: 65-83.

Sánchez López, Cristina (1999). «Los cuantificadores: clases de cuantificadores y estructuras cuantificativas». In: Ignacio Bosque; Demonte, Violeta (dirs.). Gramática descriptiva de la lengua española. Madrid: Espasa-Calpe, vol. 1, pp. 1025-1128.

Vincent, Nigel (1997). «The emergence of the D-System in Romance». In: van Kemenade, Ans; Vincent, Nigel (eds.). Parameters of Morphosyntactic Change. Cambridge: Cambridge University Press, pp. 149-169.

Zamparelli, Roberto (2000). Layers in the Determiner Phrase. New York - London: Garland. 